\title{
Analysis and validation of a quasi-dynamic model for a solar collector field with flat plate collectors and parabolic trough collectors in series for district heating
}

Tian, Zhiyong; Perers, Bengt; Furbo, Simon; Fan, Jianhua

Published in:

Energy

Link to article, DOI:

10.1016/j.energy.2017.09.135

Publication date:

2018

Document Version

Peer reviewed version

Link back to DTU Orbit

Citation (APA):

Tian, Z., Perers, B., Furbo, S., \& Fan, J. (2018). Analysis and validation of a quasi-dynamic model for a solar collector field with flat plate collectors and parabolic trough collectors in series for district heating. Energy, 142, 130-138. https://doi.org/10.1016/j.energy.2017.09.135

\section{General rights}

Copyright and moral rights for the publications made accessible in the public portal are retained by the authors and/or other copyright owners and it is a condition of accessing publications that users recognise and abide by the legal requirements associated with these rights.

- Users may download and print one copy of any publication from the public portal for the purpose of private study or research.

- You may not further distribute the material or use it for any profit-making activity or commercial gain

- You may freely distribute the URL identifying the publication in the public portal 
Analysis and validation of a quasi-dynamic model for a solar collector field with flat plate collectors and parabolic trough collectors in series for district heating

\author{
Zhiyong Tian, Bengt Perers, Simon Furbo and Jianhua Fan
}

Department of Civil Engineering, Technical University of Denmark, Kgs. Lyngby, Denmark

\begin{abstract}
A quasi-dynamic TRNSYS simulation model for a solar collector field with flat plate collectors and parabolic trough collectors in series was described and validated. A simplified method was implemented in TRNSYS in order to carry out long-term energy production analyses of the whole solar heating plant. The advantages of the model include faster computation with fewer resources, flexibility of different collector types in solar heating plant configuration and satisfactory accuracy in both dynamic and long-term analyses. In situ measurements were taken from a pilot solar heating plant with $5960 \mathrm{~m}^{2}$ flat plate collectors and 4039 $\mathrm{m}^{2}$ parabolic trough collectors in series in Taars, Denmark from Sep.2015 to Aug.2016. The simulated thermal performances of both the parabolic trough collector field and the flat plate collector field have a good agreement with the measured performances. The thermal performance of the hybrid solar district heating plants is also presented. The measured and simulated results show that the integration of parabolic trough collectors in solar district heating plants can guarantee that the system produces hot water with relatively constant outlet temperature. The daily energy output of the parabolic trough collector field can be more than $5 \mathrm{kWh} / \mathrm{m}^{2}$, while the daily energy output of the flat plate collector field is less than $5 \mathrm{kWh} / \mathrm{m}^{2}$ under Danish climate conditions. The simplified and validated TRNSYS model can be a useful tool to simulate and optimize thermal performance of solar heating plants with both flat plate and parabolic trough collectors.
\end{abstract}

Keywords, Hybrid solar district heating plants; quasi-dynamic model; validation; in-situ measurements

\title{
1. Introduction
}

The number of large scale solar heating plants for district heating increased very fast in Europe during the last couple of years, especially in Denmark [1], [2]. More than 70\% of large scale solar heating plants for district heating around the world are constructed in Denmark so far [3]. Most of the collectors in the existing plants are flat plate collectors. Due to collector heat losses, the efficiency of flat plate solar collectors is significantly lower at operation temperatures of $85^{\circ} \mathrm{C}-95^{\circ} \mathrm{C}$ compared to the efficiency at temperatures of $40^{\circ} \mathrm{C}-60^{\circ} \mathrm{C}$. Parabolic trough collectors typically have a low heat loss coefficient and are therefore less affected by the operation temperature level of the collectors. Parabolic trough collector is the most used technology currently among solar concentrating power collector technologies [4]. Parabolic trough collectors are mainly used for electricity production at temperatures of $200-400^{\circ} \mathrm{C}$ so far [5], [6]. Industry process temperatures found in industrial processes are manifold, ranging from low $\left(\mathrm{T}<100^{\circ} \mathrm{C}\right)$, medium $\left(100^{\circ} \mathrm{C}<\mathrm{T}<\right.$ $\left.250^{\circ} \mathrm{C}\right)$ to high $\left(\mathrm{T}>250^{\circ} \mathrm{C}\right)$ operating temperatures [7]. Parabolic trough collector is also suitable for these temperature ranges [7]. More and more parabolic trough collectors have been employed in the industry process heat production in the recent years [6], [8]-[11]. Most small scale parabolic trough heating plants are applied for industry processes using glycol/water as heat transfer fluid in recent years [7]. Parabolic trough collector also can be used with advantage operated at temperature range $85-95^{\circ} \mathrm{C}$ in solar district heating plants. The feasibility of parabolic trough collectors in large scale solar heating plants for district heating has been validated in the pilot Thisted plant in Denmark in 2013 [12]. A pilot solar collector system with flat 
plate collector and parabolic trough collector fields for district heating networks in series can harvest the advantages of the flat plate collectors at low temperature levels and the parabolic trough collectors at high temperature levels. A combined solar heating plant with $5960 \mathrm{~m}^{2}$ flat plate collectors and $4039 \mathrm{~m}^{2}$ parabolic trough collectors in series for a district heating network was constructed in Taars, Denmark in 2015 [13][15]. A general solar collector field model for both flat plate and parabolic trough collectors would be essential for the evaluation of the combined system.

\subsection{Single solar collector model}

Many test methods for single solar collectors have been developed [16-28]. The test methods can be divided into the steady-state method, quasi-dynamic method and dynamic method. The quasi-dynamic method is used in the model in this paper. The quasi-dynamic test (QDT) method described in most of the common standards such as EN 12975-2 [16], ISO 9806:2013 [17] and ASHRAE 93 [18] is an efficient model applicable to both concentrating and non-concentrating collector designs, which is firstly developed by Bengt Perers in 1990s [19]-[21]. Fischer, S., et al. [22] also showed that the QDT method can be used to predict the performance of single parabolic trough collector. Some improved dynamic methods were developed by Deng J. and Kong W. et al. [23]-[28].

\subsection{Solar collector field model}

B. Perers [29] had introduced several solar collector models to MINSUN simulation program, which can simulate the thermal performance of different collector fields in 1990. The results had shown that parabolic trough collectors with good optical performance had thermal performance comparable to flat plate or evacuated tube collectors at high latitudes. B. Perers. et al. also investigated the application of parabolic trough collectors in a small scale pilot plant in Thisted, Denmark [12]. This was the earliest research about the practical application of parabolic trough collectors at high latitudes. Guadalfajara M. et al. developed a simple method to simulate the performance of central solar heating plants with seasonal storage [30]. The simple method could give an overview of the thermal performance of solar heating plant which can be helpful for pre-design of the large solar heating plants. The disadvantage of the simple method is that the shadow among the collectors and control strategy is not taken into consideration. Marco. et al. [31] investigated a $1070 \mathrm{~m}^{2}$ flat plate collector field for the industry process heat, which focused on thermal performance of the solar collector field by comparing the measured field efficiency with the nominal collector efficiency. Hassine I B. et al. [32] also investigated two about $1000 \mathrm{~m}^{2}$ solar heating plants. Control strategy in the primary and second loop was optimized to have a constant outlet temperature. Frank E. et al. [33] evaluated the operation performance of two around $1000 \mathrm{~m}^{2}$ parabolic trough collector fields in Switzerland. A quasi-dynamic simulation model for direct steam generation in parabolic trough collector loops using TRNSYS was introduced [34].

\subsection{Scope}

The previous studies [16-28] mainly focus on simulation or test on a single collector in the laboratory, direct steam generation [34] and thermal performance of relatively small scale solar collector fields $\left(1000 \mathrm{~m}^{2}\right)$ [30-34]. A collector array field may consist of collectors connected in series and in parallel. Thermal performance of the total collector array should be determined by both the number of modules in series and the characteristics of each module. Most studies were on the flat plate collector. Currently, the performances of large scale solar collector fields under real operation conditions have not yet been widely documented and standardized. Evaluating thermal performance of large-scale solar collector fields with good accuracy is still an important topic in the large scale solar heating industry. Technical parameters from a standard efficiency test of single collector can be used to simulate the thermal performance of total solar collector arrays. Compared to solar collector models, solar collector field model also should consider row shading, axis 
orientation, heat losses in pipes .etc. A simple and practical method to predict thermal performance of different solar collector fields for general use can increase confidence of large solar heating plants technology in the market. The quasi-dynamic collector model is applied to simulate thermal performance of a nearly $10000 \mathrm{~m}^{2}$ hybrid solar collector field in Denmark. The quasi-dynamic collector field model was validated by the almost annual in-situ measurements of both flat plate and parabolic trough collector field. The validated quasi-dynamic collector field model could be a very useful tool to optimize the combined solar heating plant to determine the optimal design parameters. The novelty of this study is summarized as follows: 1, The objective is a novel large-scale solar district heating plant with flat plate collectors and parabolic trough collector in series. 2, Validation of the quasi-dynamic model for both large-scale flat plate collector and parabolic trough collector fields was shown; 3, Both simulated and measured dynamic performances of the novel hybrid solar collector field were presented; 4, The advantages of the hybrid solar heating plant were shown, which can introduce a new design concept of large-scale solar district heating plants to other places.

\section{Taars solar heating plant}

The Taars solar heating plant is located in Taars, $30 \mathrm{~km}$ north of Aalborg, Denmark. The solar heating plant is the first demonstration project with parabolic trough collectors for district heating in Europe. The plant was put into operation in August.2015, as shown in Fig.1. Fig. 2 illustrates the layout of the solar collector field. The PTC collector field consists of six rows of PTC collectors with $4039 \mathrm{~m}^{2}$ aperture area and the orientation of the PTC collectors is $13.4^{\circ}$ towards west from south. The flat plate collector field in the right of Fig. 1 consists of $5960 \mathrm{~m}^{2}$ aperture area and the orientation is south. The tilt of the flat plate collector field is $50^{\circ}$. The row distances for the parabolic trough collector field and the flat plate collector field are $12.6 \mathrm{~m}$ and $5.67 \mathrm{~m}$ respectively. The solar collector fluid of the parabolic trough collector field and the flat plate collector field is water and mixture of glycol/water (35\%) respectively. The FPC field preheats the return water from the district heating networks to about $75^{\circ} \mathrm{C}$. Then the preheated water from the FPC field is heated by the PTC field to $95^{\circ} \mathrm{C}$. The system was measured over a year (Sep.2015 - Aug.2016). Two heat storage tanks $\left(2430 \mathrm{~m}^{3}\right.$ in total) were used for the heat storage of several summer days. Tables 1 and 2 show the geometrical parameters of FPC and PTC separately [13][35].

\section{TRNSYS model based on quasi-dynamic method}

A flat plate collector field and a parabolic trough collector field model were established in TRNSYS [36]. In the flat plate collector field, heat exchanger unit, shadows and pipes are included. The collector arrays consist of collectors connected in series and in parallel. There are two kinds of flat plate collector with/without FEP foil between absorber and cover glass used in the flat plate collector field. The flat plate collector field has 39 rows in parallel. 6 FPC collectors without foil in series and other 6 FPC collectors with foil in series in average were used in each row. In the parabolic trough collector loop, shadows, supply pipes and return pipes of the solar collector field are taken into consideration. The thermal performance of the total collector array is determined by the number of modules in series and the characteristics of each module. The numbers of modules per row of both FPC and PTC are 12 and 10, respectively. The discretization in the modelling is done inside the collector and pipe models used. Each collector array is discretized with nodes. The solar collector field model can simulate an array of identical solar collectors hooked up in series. The number of nodes is used to specify how many collectors are hooked up in a series arrangement (outlet of first collector $=$ inlet of second collector, etc.) for each parallel flow loop. 
The type 1290 is used to simulate thermal performance of both parabolic trough collector and flat plate collector field. The Type 1290 is based on EN12975-2 Dynamic Efficiency Approach (ASHRAE IAMs) [37].

The solar collector model equation is given as follows,

$$
\begin{gathered}
\frac{Q}{A}=\eta_{0} K_{\theta b}(\theta) G_{b}+\eta_{0} K_{\theta d}(\theta) G_{d}-c_{1}\left(\mathrm{~T}_{m}-T_{a}\right)-c_{2}\left(\mathrm{~T}_{m}-T_{a}\right)^{2}-c_{3} \frac{d T_{m}}{d t} \text { (eq.01) } \\
K_{\theta b}(\theta)=1-b_{0}\left(\frac{1}{\operatorname{Cos} \theta}-1\right)-b_{1}\left(\frac{1}{\operatorname{Cos} \theta}-1\right)^{2}, \theta \leq 60^{\circ} \text { (eq.02) }
\end{gathered}
$$

When $\theta>60^{\circ}$, the IAM is linearized from the value at $60^{\circ}$ to a value of zero at $90^{\circ}$.

Total radiation $G$ is divided into the beam $G_{b}$ and diffuse $G_{d}$ parts in this collector model. Incident angle modifiers are used for beam radiation and diffuse radiation. $\mathrm{K}_{\theta b}(\theta)$ is a function of the angle of incidence of the direct radiation and the constant $\mathrm{K}_{\theta \mathrm{d}}$ for the diffuse radiation. Thus the collector model can be used to predict the thermal performance of both the parabolic collectors and the flat plate collectors.

Type 30 was employed to simulate shadows from the solar collectors for both collector subfields. This component determines incident radiation upon an array of collectors with shadows from the row in front of the row in question. There are two possible modes. Model 1 considers shadows from fixed flat plate collectors with a tilt. Total, beam, and diffuse radiation are output. Model 2 is for single axis tracking parabolic trough collectors that utilize beam radiation only. Type 5 was used to simulate the heat exchanger connected to the FPC field. Type 31 was used to simulate the pipes. Measured DNI and global horizontal solar radiation and inlet temperature etc. are inputs used for model validation. Measurements and uncertainties can be found in section 4. Mathematical descriptions on the components can be found in [37].

(1) Flat plate collectors

The flat plate collectors, HTHEATboost 35/10 without FEP foil and HTHEATstore 35/10 with FEP foil, are produced by Arcon-Sunmark [35]. Standard parameters for the collectors based on gross areas can be found in Table 3 [38]. Total radiation on the flat plate collector is input for the flat plate collector field model. Two separate 1290 type components in series are used to simulate the thermal performance of the flat plate collector without and with FEP foil in series.

(2) Parabolic trough collectors

Peak collector efficiency $\eta_{0}$ and the heat loss coefficients $c_{1}$ and $c_{2}$ for the parabolic trough collectors were assumed to be equal to the values of the pilot plant in Thisted, Denmark [14], as shown in table 4. Beam radiation on the PTC plane calculated by measured DNI and zenith angle are inputs for the parabolic trough collector field model.

\section{Measurements and uncertainties}

\subsection{Measurements}

The solar heating plant system is well equipped with different accurate sensors. Total solar radiation on the collector's surface and global radiation, ambient temperature and wind speed data were measured. It also 
had temperature sensor inputs onto which SIEMENS TS500 thermometer with drilled thermoswell temperature sensors [39] were connected to measure inlet and outlet temperatures of both flat plate collector field and parabolic trough collector field. The volume flow rate of the solar fluid was measured using Sitrans FM MAG3100 P flow meters from SIEMENS. The TS500 temperature sensors (PT100) have an uncertainty of $\pm 0.30 \mathrm{~K}+0.0050^{*}|\mathrm{~T}[\mathrm{~K}]|[39]$. Sitrans FM MAG3100 P flow meters had an uncertainty of $1 \%$ (maximum).

Two pyranometers (Kipp\&Zonen SMP11) are used to measure the global radiation on the horizontal surface and total radiation on the tilted flat plate collector [40]. DNI is measured by the PMO6-CC pyrheliometer [41] with the sun tracking platform Sunscanner SC1 [42], which has high accuracy and automatically cleaning function. The solar radiation sensors had an accuracy of $2 \%$ and a resolution of 1 $\mathrm{W} / \mathrm{m}^{2}$. All the raw measurement data was logged at 1 min interval.

\subsection{Uncertainties}

Measured power output is calculated by eq.3. Separate uncertainty of each parameter causes uncertainty of the measured power. As shown in section 4.1, uncertainty of the flow rate sensor is $1 \%$. Uncertainties of density and specific heat of water or glycol/water mixture are estimated as $0.5 \%$. By equation 4 , typical uncertainties of the measured power output of the FPC field and the PTC field can be calculated. Details can be found in Figs. 5, 7, 10 and 12 in section 5.

$$
Q=V \times \rho \times C_{P} \times\left(\mathrm{T}_{\text {out }}-\mathrm{T}_{\text {in }}\right) \quad(\text { eq. } 03)
$$

$$
S(Q)=\sqrt{\left(\frac{\partial Q}{\partial V} \cdot S_{v}\right)^{2}+\left(\frac{\partial Q}{\partial \rho} \cdot S_{\rho}\right)^{2}+\left(\frac{\partial Q}{\partial C_{p}} \cdot S_{C_{p}}\right)^{2}+\left(\frac{\partial Q}{\partial T_{\text {out }}} \cdot S_{t_{\text {out }}}\right)^{2}+\left(\frac{\partial Q}{\partial T_{\text {in }}} \cdot S_{t_{\text {tu }}}\right)^{2}}
$$

\section{Validation}

Section 5.1 shows dynamic comparisons of measured and modelled performance of the flat plate collector field and the parabolic trough collector field in a cloudy and a sunny day. Section 5.2 illustrates daily and monthly comparisons of measured and modelled performances based on the quasi-dynamic model. The time step of all the calculations is 1 minute. Inlet temperature and volume flow rate of both the FPC and the PTC field in simulation are taken from the measurements from the Taars plant.

\subsection{Dynamic performance in typical days}

One sunny day (May 7, 2016) and one typical cloudy day (August 14, 2016) were selected to analyze the thermal performance and validate the developed model. Figs. 3 and 8 show that weather conditions, such as ambient temperature, DNI, global radiation and total radiation on the south-oriented tilted collector plate $\left(50^{\circ}\right)$ and flow rates of both days, respectively. The measured and simulated outlet temperature and power output of the FPC field shown in this section are the values of the secondary water loop of the FPC field including the heat exchanger.

\subsubsection{Sunny day (May 7 of 2016)}

As shown in Fig. 3, May 7 in 2016 was a typical sunny day. The maximum of global radiation on the tilted surface was about $1000 \mathrm{~W} / \mathrm{m}^{2}$ and the max DNI was about $800 \mathrm{~W} / \mathrm{m}^{2}$. The ambient temperature peaks at around $30^{\circ} \mathrm{C}$. Measured volume flow rates of both the FPC and the PTC fields are shown in Fig.3. Since 
the PTC field tracked the sun from sunrise to sunset during the daytime, the operation period of the PTC field is longer than that of the FPC field. In the sunny day, the flow rate of PTC field was almost constant. The volume flow rate of the FPC field varied with the solar radiation and was largest at noon.

\section{1) FPC field on the sunny day}

Fig. 4 shows measured inlet and outlet temperature and simulated outlet temperature of the FPC field in May 7, 2016. Fig. 5 shows measured and modelled power output of the FPC field in May 7, 2016. The maximum power output of the flat plate collector field is close to $600 \mathrm{~W} / \mathrm{m} 2$ at noon in May 7, 2016. The modelled and measured outlet temperature, the modelled and measured power output have good agreements in Figs. 4 and 5.

\section{2) PTC field on the sunny day}

Fig. 6 shows measured inlet and outlet temperature and simulated outlet temperature of the PTC field in May 7, 2016. Fig. 7 illustrates the comparison between measured and modelled power output of the parabolic trough collector field in May 7, 2016. The modelled results have similar fluctuations as the measured results. As shown in Fig. 7, the measured and modelled thermal performances of the PTC field had a good agreement. Compared to the thermal performance of the FPC field at noon, the thermal performance of the PTC field was a bit higher before and after noon. That was because of tracking the sun. It also can be seen in Fig. 7 that there was an increase of power output after sunset. That was due to discharge of the heat stored in the receiver. The low heat losses of the parabolic trough collectors means that this can be done even after sunset. It is also found that the outlet temperature of the PTC field is relatively constant, which is very important for the hydraulic balance of the district heating network.

\subsubsection{Cloudy day (August 14 of 2016)}

August 14 in 2016 was a cloudy day. As shown in the Fig. 8, the maximum of DNI and global solar radiation was larger than $800 \mathrm{~W} / \mathrm{m}^{2}$. Fig. 8 shows the fluctuation of weather from 9:30 am to 19:30 pm in August 14, 2016. Both the DNI and the global solar radiation fluctuated dramatically during the daytime. The total solar radiation on the tilted flat plate collector was larger than that on the horizontal surface. The largest total radiation on the tilted solar collector in short periods exceeded $1200 \mathrm{~W} / \mathrm{m}^{2}$. On the cloudy day, the flow rates of both collector fields fluctuated along with the solar radiation.

1) FPC field on the clouy day

Fig. 9 shows measured inlet and outlet temperature and simulated outlet temperature of the FPC field in August 14, 2016. Fig. 10 shows measured and modelled power output of the FPC field in August 14, 2016. The modelled and measured power outputs had very similar fluctuation trends.

2) PTC field on the clouy day

Fig. 11 shows measured inlet and outlet temperature and simulated outlet temperature of the PTC field in August 14, 2016. Fig. 12 shows the measured and modelled power output of the PTC field on a cloudy day (August 14, 2016). The maximum of power output in August 14, 2016 was higher than $500 \mathrm{~W} / \mathrm{m}^{2}$. The modelled power output has almost the same fluctuating change as the measured power output.

The daily energy output of the FPC and PTC fields are shown in Table 5. The modelled and measured energy outputs present a good agreement on both cloudy and sunny days. The measured energy output of the PTC field is a bit lower than the modelled values on both the cloudy and the sunny days. That may be due to 
dirt on the mirror of the parabolic trough collectors because the mirrors have not been washed yet since August 2015. Furthermore, compared to the energy output of the FPC field, the PTC field produced $40 \%$ more solar heat than the FPC field on the sunny day.

\subsection{Daily and Monthly performance}

Calculations of daily and monthly performances of both solar collector fields are based on 1 minute time steps. The daily and monthly thermal performances of the parabolic trough collector field and the flat plate collector field during year-around are presented in Figs. 13-16.

1) Flat plate collector field

Fig. 13 shows that the measured and the modelled thermal performances are strongly linear related. Overall, the modelled results have a fine match with the measured data. The max daily solar heat production of the flat plate collector field was below $5 \mathrm{kWh} / \mathrm{m}^{2} /$ day.

As shown in Fig. 14, the flat plate collector field produced small heat quantities in November - January. The FPC field produced more and more heat from January to April. The FPC field produced more than 50 $\mathrm{kWh} / \mathrm{m}^{2}$ in April. The measured and simulated monthly solar heat productions show a good agreement from Sep.2015 to Aug.2016.

\section{2) Parabolic trough collector field}

Daily and monthly measured and modelled energy outputs of the PTC field (Sep.2015-Apr.2016) are shown in Figs. 15-16. In Fig. 15, a single point represents a daily result (September.2015-April.2016). There is a strong linear correlation between the measured daily thermal performance and the modelled daily thermal performance in Fig. 15, which shows the modelled values have good agreement with the measured values. Due to the oversized flat plate collector field and low heat load in the summer, the parabolic trough collector field was defocused on several sunny days in the summer. Therefore, only thermal performances of the parabolic trough collector field without defocusing during the period from Sep.2015 to Apr.2016 was presented in this section to verify the TRNSYS model. The maximum daily thermal performance of the parabolic trough collector field can be higher than $5 \mathrm{kWh} / \mathrm{m}^{2} /$ day, while the max daily thermal performance of the flat plate collector field is below $5 \mathrm{kWh} / \mathrm{m}^{2} /$ day. The thermal energy output of both the flat plate collector field and parabolic trough collector field in November, December, January is quite low because of the low solar radiation in winter. From February, the thermal energy output of the parabolic trough collector array increased dramatically because of more sunny days and the PTC field produced more solar heat than the FPC field.

\section{Discussions}

The flat plate collector field preheats return water from $45^{\circ} \mathrm{C}$ up to $70^{\circ} \mathrm{C}$, and then the preheated water is heated to $95^{\circ} \mathrm{C}$ by the parabolic trough collector field in the Taars plant. The design strategy that the PTC field produces the high temperature water also guarantees that the FPC field has better performance and higher efficiency due to relatively low operation temperature compared to normal flat plate collector fields. In addition, section 5 shows that the TRNSYS models of the FPC field and the PTC field have quite good agreement with measurements. The PTC field was defocused sometimes in the quite sunny days in summer (May - August) because the flat plate collector field was oversized and the heat load of the district heating networks in summer was low. So Figs. 17 and 18 only show the measured results from Sep.2015-Apr.2016. The PTC field would have higher energy output than the measured values, if the parabolic trough collectors 
were not defocused on sunny days in the summer. On the other hand, the defocusing of the PTC field can avoid boiling problems of the solar collector field in the summer season.

\section{Conclusions and future work}

The quasi-dynamic simulation model of both large parabolic trough collector field and flat plate collector field was validated by the measured thermal performance of the Taars solar heating plant in Denmark. Dynamic performance on two typical days was selected for the detailed validation. The simulated and the measured daily and monthly performances of the solar heating plant were also compared. The following conclusions can be drawn:

(1) The quasi-dynamic method with the technical parameters from the standard test report based on single collector can be used to predict the thermal performance of both parabolic trough collector and flat plate collector fields.

(2) The daily energy output of the parabolic trough collector field can be more than $5 \mathrm{kWh} / \mathrm{m}^{2}$, while the daily energy output of the flat plate collector field is less than $5 \mathrm{kWh} / \mathrm{m}^{2}$ under Danish climate conditions.

(3) The integration of parabolic trough collectors can increase the flexibility of solar district heating plants. The parabolic trough collectors can be easily defocused in the summer to avoid the overheat production. The flat plate collectors only work at low temperature range in the hybrid solar heating plant in order to increase the thermal performance of the flat plate collectors, compared to normal existing solar heating plants. A relatively constant and high outlet temperature of the hot water is easily achieved in the hybrid solar district heating plants.

In summary, the validated solar collector field model in this study is able to model reliable dynamic performances with a time step of 1 minute. The proposed model is cost-effective, reasonable accurate and requires low computational time. The validated model may be a useful tool to analyze long-term performance, optimize design parameters and evaluate control strategy of large solar heating plants for district heating.

\section{Acknowledgements}

The first author really appreciates the China Scholarship Council (No.201506120074) for the financial support for the Ph.D. study at the Technical University of Denmark. Special thanks are expressed to the Aalborg CSP A/S for the information provided and maintaining the high accuracy and reliablility of the measurement system (Andreas Zourellis, Jan Holst Rothman, Steffen Rovsing Møller and Per Aasted). This work is also a part of an EUDP (Energy Technology Development and Demonstration) project financed by the Danish Energy Agency and the IEA-SHC Task 55 "Towards the Integration of Large SHC Systems into DHC Networks". 


\section{Symbols}

311 Q Useful output power, W

312 A Collector array area, $\mathrm{m}^{2}$

$313 \mathrm{c}_{1} \quad$ Heat loss coefficient at $(\mathrm{Tm}-\mathrm{Ta})=0, \mathrm{~W} /\left(\mathrm{m}^{2} \cdot \mathrm{K}\right)$

$314 \quad c_{2} \quad$ Temperature dependence of the heat loss coefficient, $\mathrm{W} /\left(\mathrm{m}^{2} \cdot \mathrm{K}^{2}\right)$

$315 \quad \mathrm{c}_{3} \quad$ Effective thermal capacity, $\mathrm{kJ} /\left(\mathrm{m}^{2} \cdot \mathrm{K}\right)$

$316 \quad \mathrm{G}_{\mathrm{b}} \quad$ Beam radiation, $\mathrm{W} / \mathrm{m}^{2}$

$317 \quad \mathrm{G}_{\mathrm{d}} \quad$ Diffuse radiation, $\mathrm{W} / \mathrm{m}^{2}$

$318 \mathrm{~K}_{\theta \mathrm{b}} \quad$ Incidence angle modifier for beam radiation, -

$319 \mathrm{~K}_{\theta \mathrm{d}} \quad$ Incidence angle modifier for diffuse radiation, -

$320 \quad \mathrm{~T}_{\mathrm{m}} \quad$ Mean fluid temperature, ${ }^{\circ} \mathrm{C}$

$321 \mathrm{~T}_{\mathrm{a}} \quad$ Ambient temperature, ${ }^{\circ} \mathrm{C}$

$322 \quad \eta_{0} \quad$ Peak collector efficiency, -

$323 \mathrm{dTm} / \mathrm{dt}$ Time derivative of the mean fluid temperature, K/s

$324 \theta \quad$ Incident angle of the beam radiation, ${ }^{\circ}$

$325 \mathrm{~b}_{0} \quad$ IAM coefficient(beam radiation), -

$326 b_{1} \quad$ IAM coefficient(beam radiation), -

$327 \mathrm{G}_{\text {tilted }}$ Total solar radiation on the tilted plate, $\mathrm{W} / \mathrm{m}^{2}$

$328 \mathrm{G}_{\mathrm{h}} \quad$ Global solar radiation on the horizontal surface, $\mathrm{W} / \mathrm{m}^{2}$

$329 \mathrm{H}_{\text {Beam (PTC) }}$ Daily beam radiation on the parabolic trough collector aperture, $\mathrm{kWh} / \mathrm{m}^{2}$

$330 \mathrm{H}_{\text {Tilted (FPC) }}$ Daily total radiation on the flat plate collector aperture, $\mathrm{kWh} / \mathrm{m}^{2}$

$331 \mathrm{~T}_{\text {out }} \quad$ Outlet temperature, ${ }^{\circ} \mathrm{C}$

$332 \mathrm{~T}_{\text {in }} \quad$ Inlet temperature, ${ }^{\circ} \mathrm{C}$

$333 \rho \quad$ Density, $\mathrm{kg} / \mathrm{m}^{3}$

$334 C_{P} \quad$ Specific Heat Capacity, $\mathrm{J} /\left(\mathrm{kg}^{\circ} \mathrm{C}\right)$

$335 \mathrm{~V} \quad$ Volume flow rate, $\mathrm{m}^{3} / \mathrm{s}$

336 S Uncertainty of specific parameters 


$\begin{array}{llc}338 & \text { Abbreviation } & \\ 339 & \text { Parabolic trough collector } & \text { PTC } \\ 340 & \text { Flat plate collector } & \text { FPC } \\ 341 & \text { Heat transfer fluid } & \text { HTF } \\ 342 & \text { Incidence angle modifier } & \text { IAM } \\ 343 & \text { Direct normal irradiance } & \text { DNI } \\ 344 & \text { Heat transfer fluid } & \text { HTF } \\ 345 & \text { Concentrating solar power } & \text { CSP } \\ 346 & \text { Quasi-dynamic test } & \text { QDT } \\ 347 & \text { Fluorinated ethylene propylene FEP }\end{array}$

\section{References} $573,2015$. shc.org/solar-heat-worldwide, 2017. 2017. 176, Apr. 2016. 1210-1216, 2014.

[1] S. Furbo, J. Fan, B. Perers, W. Kong, D. Trier, and N. From, "Testing, Development and Demonstration of Large Scale Solar District Heating Systems," Energy Procedia, vol. 70, pp. 568

[2] Werner Weiss, Monika Spörk-Dür, Franz Mauthner, Solar Heat Worldwide-Global Market Development and Trends in 2016-Detailed Market Figures 2015 (2017 version). http://www.iea-

[3] F. Mauthner and W. Weiss, ". Solar heat worldwide: markets and contribution to the energy supply 2014,” Int. Energy Agency-Solar Heat. Cool. Progr., 2016.

[4] G. Morin, J. Dersch, W. Platzer, M. Eck, and A. Häberle, "Comparison of Linear Fresnel and Parabolic Trough Collector power plants,” Sol. Energy, vol. 86, no. 1, pp. 1-12, 2012.

[5] V. K. Jebasingh and G. M. J. Herbert, "A review of solar parabolic trough collector," Renew. Sustain. Energy Rev., vol. 54, pp. 1085-1091, Feb. 2016.

[6] A. Fernández-García, E. Zarza, L. Valenzuela, and M. Pérez, "Parabolic-trough solar collectors and their applications,” Renew. Sustain. Energy Rev., vol. 14, no. 7, pp. 1695-1721, Sep. 2010.

[7] IEA, "IEA-SHC Task 49," http://task49.iea-shc.org/publications, 2016. [Online]. Available: August

[8] O. Kizilkan, A. Kabul, and I. Dincer, "Development and performance assessment of a parabolic trough solar collector-based integrated system for an ice-cream factory," Energy, vol. 100, pp. 167-

[9] R. Silva, F. J. Cabrera, and M. Pérez-García, "Process Heat Generation with Parabolic Trough Collectors for a Vegetables Preservation Industry in Southern Spain,” Energy Procedia, vol. 48, pp.

[10] B. El Ghazzani, D. Martinez Plaza, R. Ait El Cadi, A. Ihlal, B. Abnay, and K. Bouabid, "Thermal 
plant based on parabolic trough collectors for industrial process heat generation in Morocco," Renew. Energy, vol. 113, pp. 1261-1275, Dec. 2017.

[11] M. Larcher, M. Rommel, A. Bohren, E. Frank, and S. Minder, "Characterization of a Parabolic trough Collector for Process Heat Applications," Energy Procedia, vol. 57, pp. 2804-2811, 2014.

[12] B. Perers, S. Furbo, and J. Dragsted, "Thermal performance of concen- trating tracking solar collectors," DTU.Report, vol. 292, no. August, 2013.

[13] A. CSP, “Aalborg CSP,” http://www.aalborgcsp.com/, 2017. [Online]. Available: July.2017.

[14] B. Perers, S. Furbo, Z. Tian, J. Egelwisse, F. Bava, and J. Fan, "Tårs 10000 m2 CSP + Flat Plate Solar Collector Plant - Cost-Performance Optimization of the Design," Energy Procedia, vol. 91, pp. 312-316, 2016.

[15] Z. Tian, B. Perers, S. Furbo, and J. Fan, “Annual measured and simulated thermal performance analysis of a hybrid solar district heating plant with flat plate collectors and parabolic trough collectors in series," Appl. Energy, vol. 205, pp. 417-427, 2017.

[16] “CEN. EN 12975-2. Thermal solar systems and components - Solar collectors -Part 2: Test methods. European Committee for Standardisation,” 2006.

[17] "Volejnik-technicke. International Standard Solar energy — Solar thermal collectors — Test methods," 2013.

[18] "ANSI/ASHRAE. ASHRAE Standard 93 methods of testing to determine thermal performance of solar collectors," 2003.

[19] B. Perers, “An improved dynamic solar collector test method for determination of non-linear optical and thermal characteristics with multiple regression," Sol. Energy, vol. 59, pp. 163-178, 1997.

[20] Bengt Perers, "Optical Modelling of Solar Collectors and Booster Reflectors under Non Stationary Conditions," 1995.

[21] B. Perers, "Dynamic Method for Solar Collector Array Testing a N D Evaluation With Standard," vol. 50, no. 6, pp. 517-526, 1993.

[22] S. Fischer, "Efficiency Testing of Parabolic trough Collectors Using the Quasi-Dynamic Test Procedure According to the European Standard en 12975," in SolarPACES 13th Symposium on Concentrating Solar power and Chemical Energy Technologies, 2006, no. June 2006.

[23] J. Deng, X. Yang, and P. Wang, "Study on the second-order transfer function models for dynamic tests of flat-plate solar collectors Part I: A proposed new model and a fitting methodology," Sol. Energy, vol. 114, pp. 418-426, Apr. 2015.

[24] J. Deng, Y. Xu, and X. Yang, "A dynamic thermal performance model for fl at-plate solar collectors based on the thermal inertia correction of the steady-state test method," Sol. Energy, vol. 76, pp. 679$686,2015$.

[25] J. Deng, X. Yang, and P. Wang, "Study on the second-order transfer function models for dynamic tests of flat-plate solar collectors Part II: Experimental validation," Sol. Energy, vol. 114, p. , 2015.

[26] W. Kong, Z. Wang, J. Fan, P. Bacher, B. Perers, Z. Chen, and S. Furbo, "An improved dynamic test method for solar collectors," Sol. Energy, vol. 86, no. 6, pp. 1838-1848, 2012.

[27] W. Kong, Z. Wang, X. Li, X. Li, and N. Xiao, "Theoretical analysis and experimental verification of 
a new dynamic test method for solar collectors," Sol. Energy, vol. 86, no. 1, pp. 398-406, 2012.

[28] C. Sun, Y. Liu, C. Duan, Y. Zheng, H. Chang, and S. Shu, "A mathematical model to investigate on the thermal performance of a flat plate solar air collector and its experimental verification," Energy Convers. Manag., vol. 115, pp. 43-51, 2016.

[29] B. Perers, Simulation and evaluation methods for solar energy systems. 1990.

[30] M. Guadalfajara, M. A. Lozano, and L. M. Serra, "A simple method to calculate Central Solar Heating Plants with Seasonal Storage," Energy Procedia, vol. 48, pp. 1096-1109, 2014.

[31] M. Cozzini, M. Pipiciello, R. Fedrizzi, I. Ben Hassine, D. Pietruschka, and R. Söll, "Performance Analysis of a Flat Plate Solar Field for Process Heat," Energy Procedia, vol. 91, pp. 11-19, 2016.

[32] I. Ben Hassine, M. C. Sehgelmeble, R. Soll, and D. Pietruschka, "Control Optimization through Simulations of Large Scale Solar Plants for Industrial Heat Applications," Energy Procedia, vol. 70, no. 0, pp. 595-604, 2015.

[33] E. Frank, H. Marty, L. Hangartner, and S. Minder, "Evaluation of measurements on parabolic trough collector fields for process heat integration in Swiss dairies," Energy Procedia, vol. 57, pp. 2743$2751,2014$.

[34] M. Biencinto, L. Gonzålez, and L. Valenzuela, "A quasi-dynamic simulation model for direct steam generation in parabolic troughs using TRNSYS," Appl. Energy, vol. 161, pp. 133-142, 2016.

[35] Arcon-Sunmark, “Arcon-Sunmark," http://arcon-sunmark.com/products. [Online]. Available: Mar.2017.

[36] TRNSYS, “Trnsys 17,” http://www.trnsys.com/. [Online]. Available: August 2017.

[37] TRNSYS website, "TRNSYS 17-a TRaNsient SYstem Simulation program-Standard Component Library Overview and Mathematical Reference," http://sel.me.wisc.edu/trnsys. [Online]. Available: Mar.2017.

[38] SP, "Technical Research Institute of Sweden," https://www.sp.se/en/Sidor/default.aspx, 2016.

[39] Simens, "Simens," https://www.siemens.com/global/en/home.html, 2016.

[40] K. SMP11, "Kipp\&Zonen SMP11," http://www.kippzonen.com/Product/202/SMP11Pyranometer\#.V35QMvl95mM, 2017.

[41] PMO6-CC, "PMO6-CC pyrheliometer," https://www.pmodwrc.ch/pmod.php?topic=pmo6, 2016.

[42] Sunscanner SC1, "Sunscanner SC1,". http//www.black-photon.de/products/sunscanner-sc1.html, 2016. 
Table 1. Geometrical parameters of the FPC in the Taars plant.

449

5.96

2.27

0.14

13.57

12.60

Aperture area, $\mathrm{m}^{2}$ 10.6

Solar collector volume, L $\mathrm{Cu}$ pipe / $\mathrm{Al}$ plate

Material

0.95

Absorption 0.05

\begin{tabular}{ccc} 
Absorber & Absorption & 0.95 \\
& Emission & 0.05 \\
\hline \multirow{2}{*}{ Insulation } & Backside & $75 \mathrm{~mm}$ mineral wool \\
& Side & $30 \mathrm{~mm}$ mineral wool \\
\hline Cover(s) & Antireflex glass(AR:3.2mm)-with/without FEP foil \\
\hline
\end{tabular}

Table 2. Geometrical parameters of the PTC in the Taars plant.

\begin{tabular}{cc}
\hline Geometrical parameters for the PTC \\
\hline Absorber tube outer diameter $(\mathrm{m})$ & 0.070 \\
Absorber tube inner diameter $(\mathrm{m})$ & 0.066 \\
Glass envelope outer diameter $(\mathrm{m})$ & 0.125 \\
Glass envelope inner diameter $(\mathrm{m})$ & 0.119 \\
Parabola width (m) & 5.77 \\
Numbers of modules per row & 10 \\
Mirror length in each module (m) & 12 \\
Geometric concentration ratio & 26.2 \\
\hline
\end{tabular}

Table 3. Efficiency parameters of flat plate collectors.

\begin{tabular}{|c|c|c|c|c|c|c|c|}
\hline$\eta_{0}$ & $\mathrm{~b}_{0}$ & $\mathrm{~b}_{1}$ & $\mathrm{~K}_{\theta \mathrm{d}}$ & $\mathrm{c}_{1},\left[\mathrm{~W} /\left(\mathrm{m}^{2} \cdot \mathrm{K}\right)\right]$ & $\mathrm{c}_{2},\left[\mathrm{~W} /\left(\mathrm{m}^{2} \cdot \mathrm{K}^{2}\right)\right]$ & $\mathrm{c}_{3},\left[\mathrm{~kJ} /\left(\mathrm{m}^{2} \cdot \mathrm{K}\right)\right]$ & \\
\hline 0.779 & 0.1 & 0 & 0.98 & 2.410 & 0.015 & 6.798 & HEATboost 35/10 \\
\hline 0.745 & 0.1 & 0 & 0.93 & 2.067 & 0.009 & 7.313 & HEATstore 35/10 \\
\hline
\end{tabular}

Table 4. Efficiency parameters of parabolic trough collectors.

\begin{tabular}{ccccccc}
\hline$\eta_{0}$ & $\mathrm{~b}_{0}$ & $\mathrm{~b}_{1}$ & $\mathrm{~K}_{\theta \mathrm{d}}$ & $\mathrm{c}_{1},\left[\mathrm{~W} /\left(\mathrm{m}^{2} \cdot \mathrm{K}\right)\right]$ & $\mathrm{c}_{2},\left[\mathrm{~W} /\left(\mathrm{m}^{2} \cdot \mathrm{K}^{2}\right)\right]$ & $\mathrm{c}_{3},\left[\mathrm{~kJ} /\left(\mathrm{m}^{2} \cdot \mathrm{K}\right)\right]$ \\
\hline 0.75 & 0.27 & 0 & 0.038 & 0.04 & 0 & 4 \\
\hline
\end{tabular}




\begin{tabular}{|c|c|c|c|c|c|c|c|}
\hline & $\begin{array}{c}\mathrm{H}_{\text {Beam (PTC), }} \\
\mathrm{kWh} / \mathrm{m}^{2}\end{array}$ & $\begin{array}{c}\mathrm{H}_{\text {Tilted (FPC) }} \\
\mathrm{kWh} / \mathrm{m}^{2}\end{array}$ & $\begin{array}{c}\text { Measured, } \\
\mathrm{kWh} / \mathrm{m}^{2}\end{array}$ & $\begin{array}{c}\text { Modelled, } \\
\mathrm{kWh} / \mathrm{m}^{2}\end{array}$ & $\begin{array}{c}\text { Difference, } \\
\mathrm{kWh} / \mathrm{m}^{2}\end{array}$ & Deviation & \\
\hline \multirow{2}{*}{$\begin{array}{c}\text { Sunny day } \\
\text { (May 7, 2016) }\end{array}$} & \multirow{2}{*}{8.59} & \multirow{2}{*}{7.67} & 3.65 & 3.69 & 0.04 & $1.10 \%$ & FPC \\
\hline & & & 5.19 & 5.34 & 0.15 & $3.00 \%$ & PTC \\
\hline \multirow{2}{*}{$\begin{array}{c}\text { Cloudy day } \\
\text { (Aug. 14, 2016) }\end{array}$} & \multirow{2}{*}{5.37} & \multirow{2}{*}{5.90} & 2.63 & 2.59 & -0.04 & $-1.70 \%$ & FPC \\
\hline & & & 2.72 & 2.82 & 0.1 & $3.90 \%$ & PTC \\
\hline
\end{tabular}

462

463

464

465

466

467

468

469

470

471

472

473

474

475

476

477

478

479

480

481

482

483

484 
485

486

487

488

489

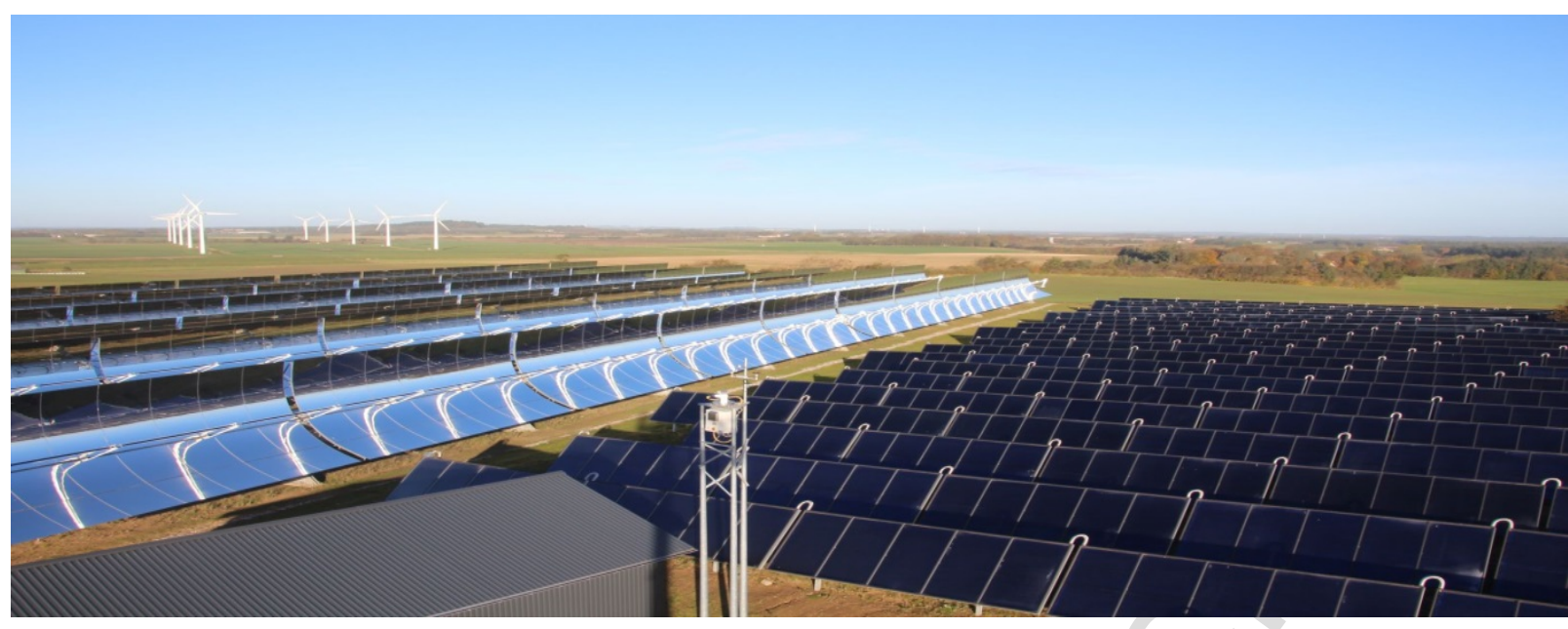

Fig.1. Solar collector fields in the Taars solar heating plant.

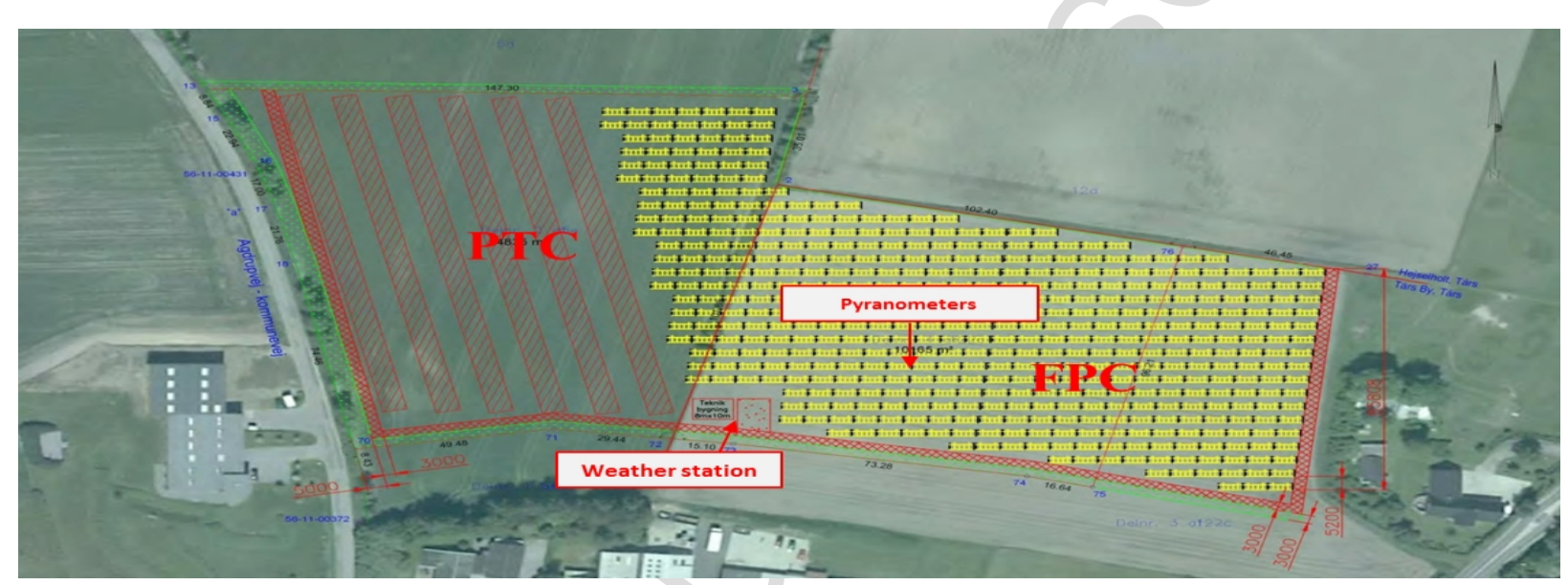

Fig.2. Layout of the parabolic trough collector and flat plate collector fields [15]. 


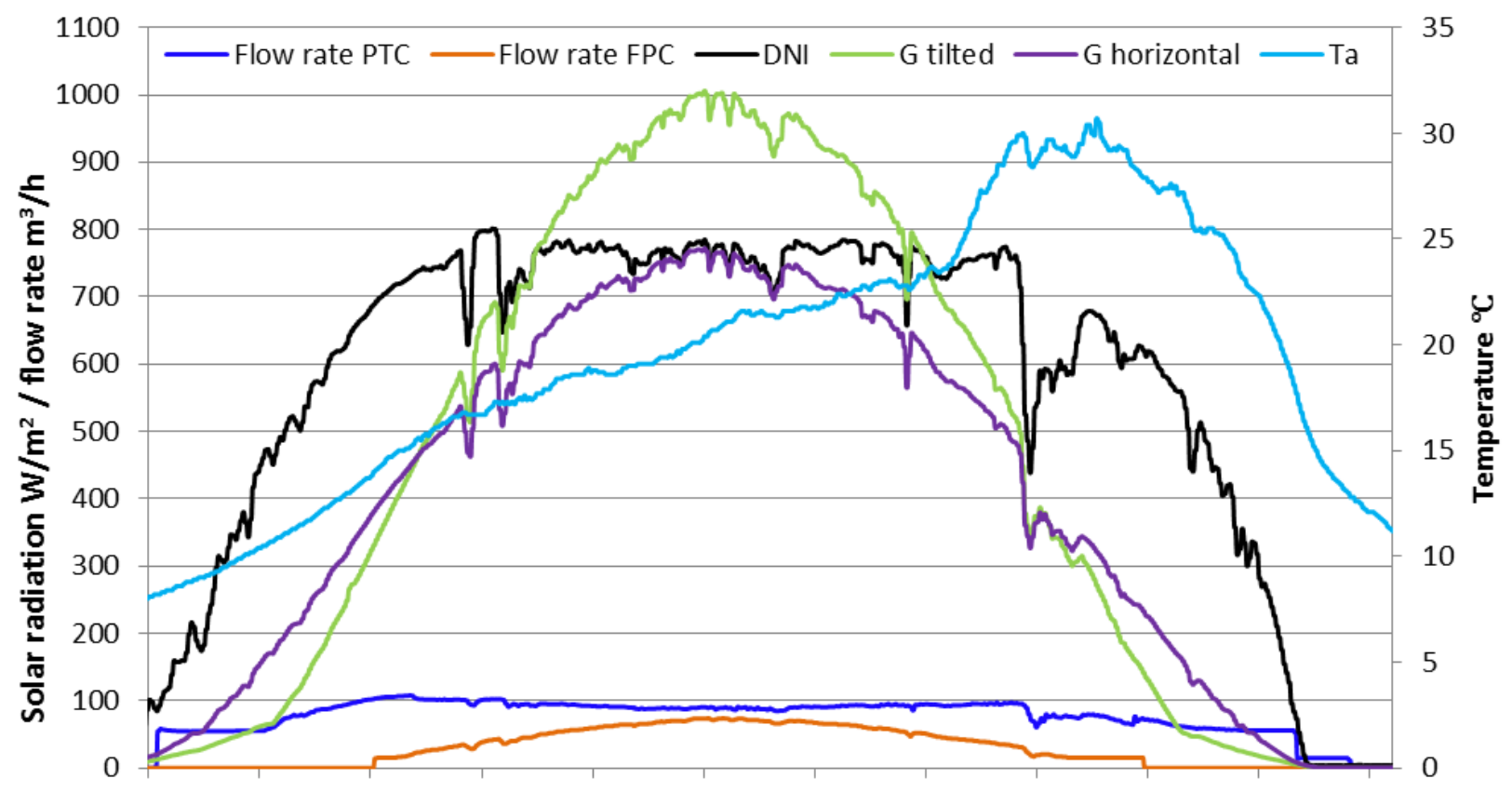

Fig.3. Global solar radiation, total tilted radiation, DNI, ambient temperature and flow rates on the sunny day 492 (May 7, 2016).

493

494

495

496 


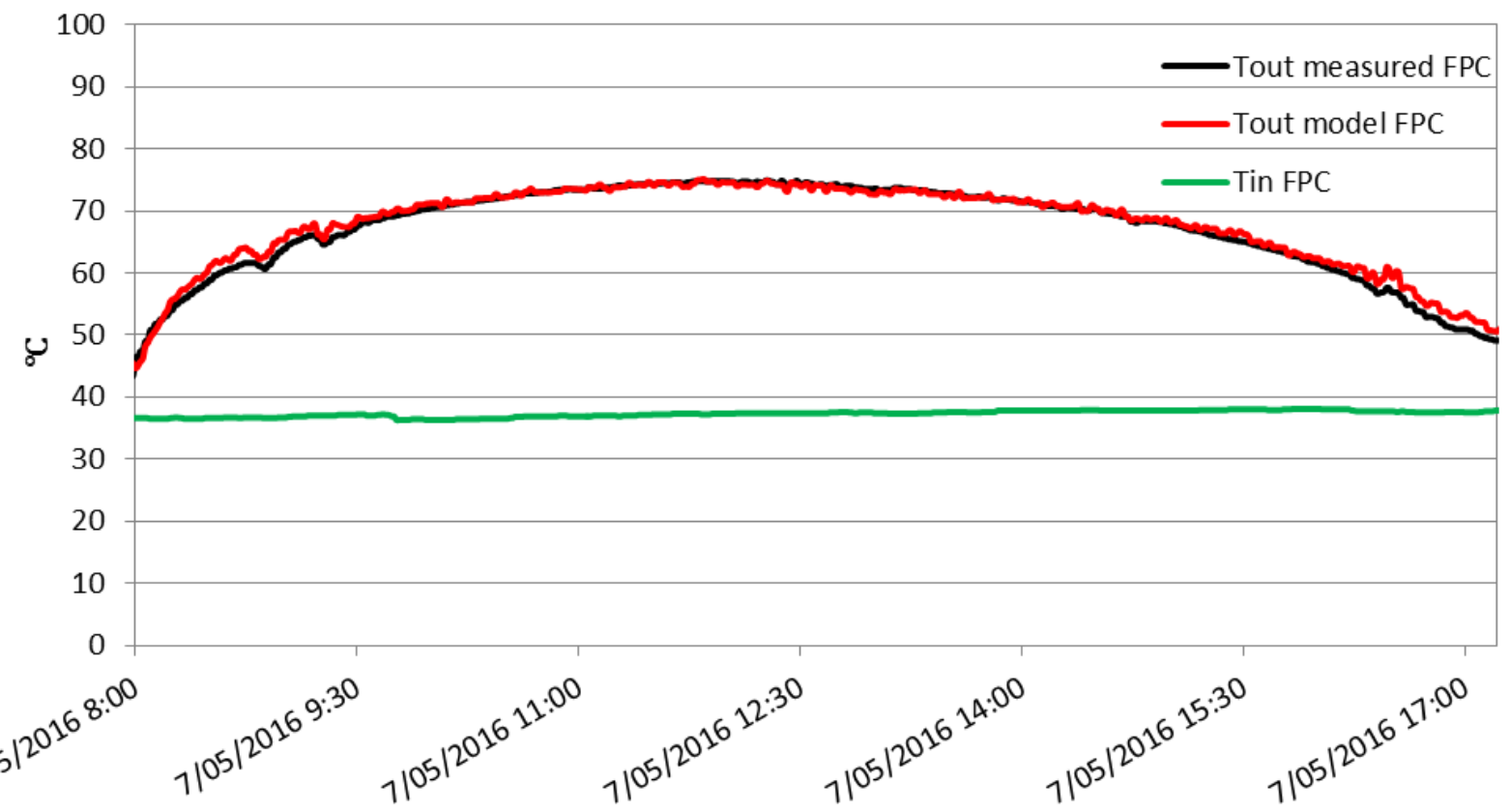

$71^{051201^{12}}$

$10^{051200^{120}}$

Fig.4. Inlet temperature, measured and modelled outlet temperature of the FPC field on the sunny day.

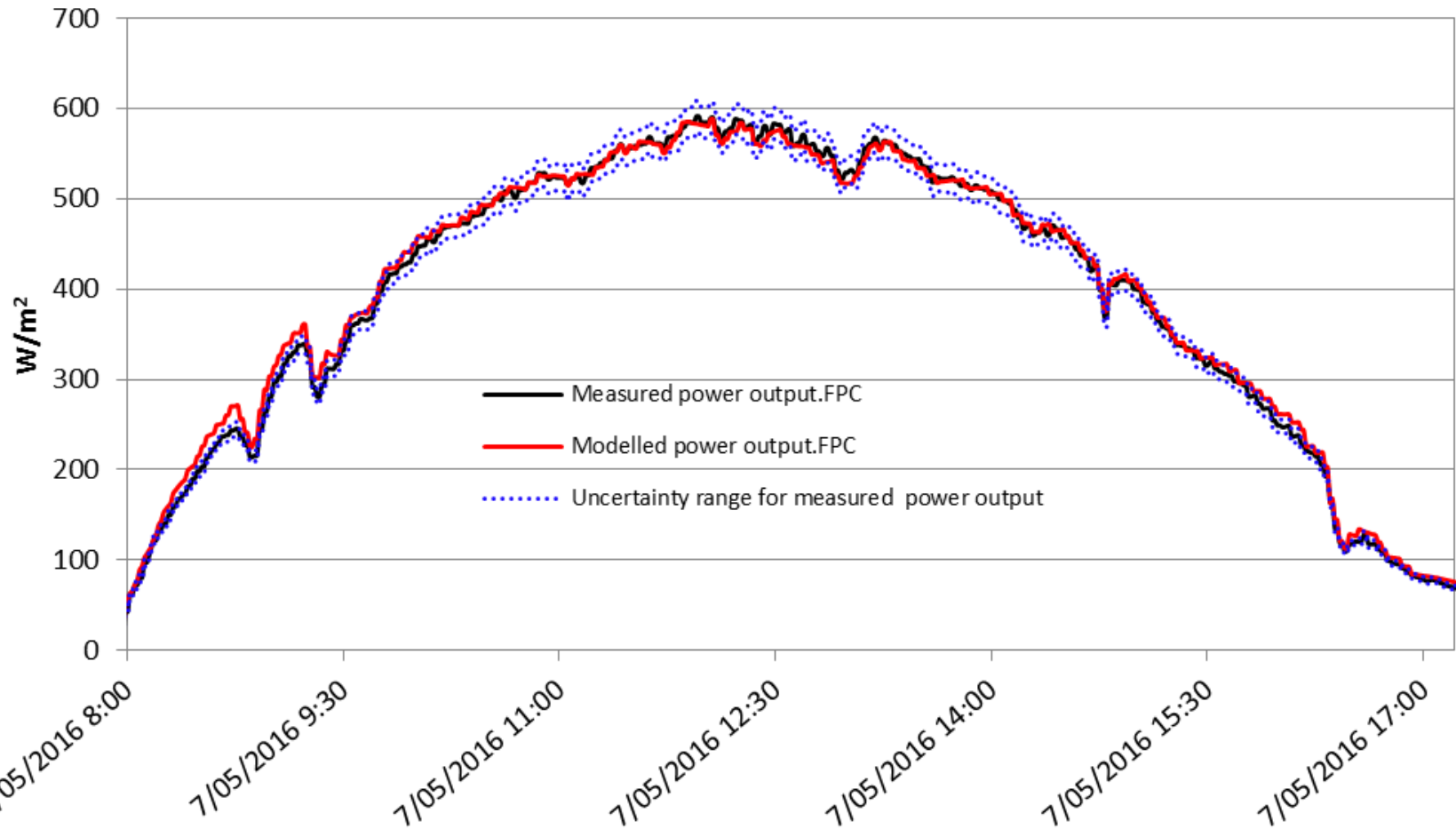

Fig.5. Measured and modelled power output of the FPC field on the sunny day. 


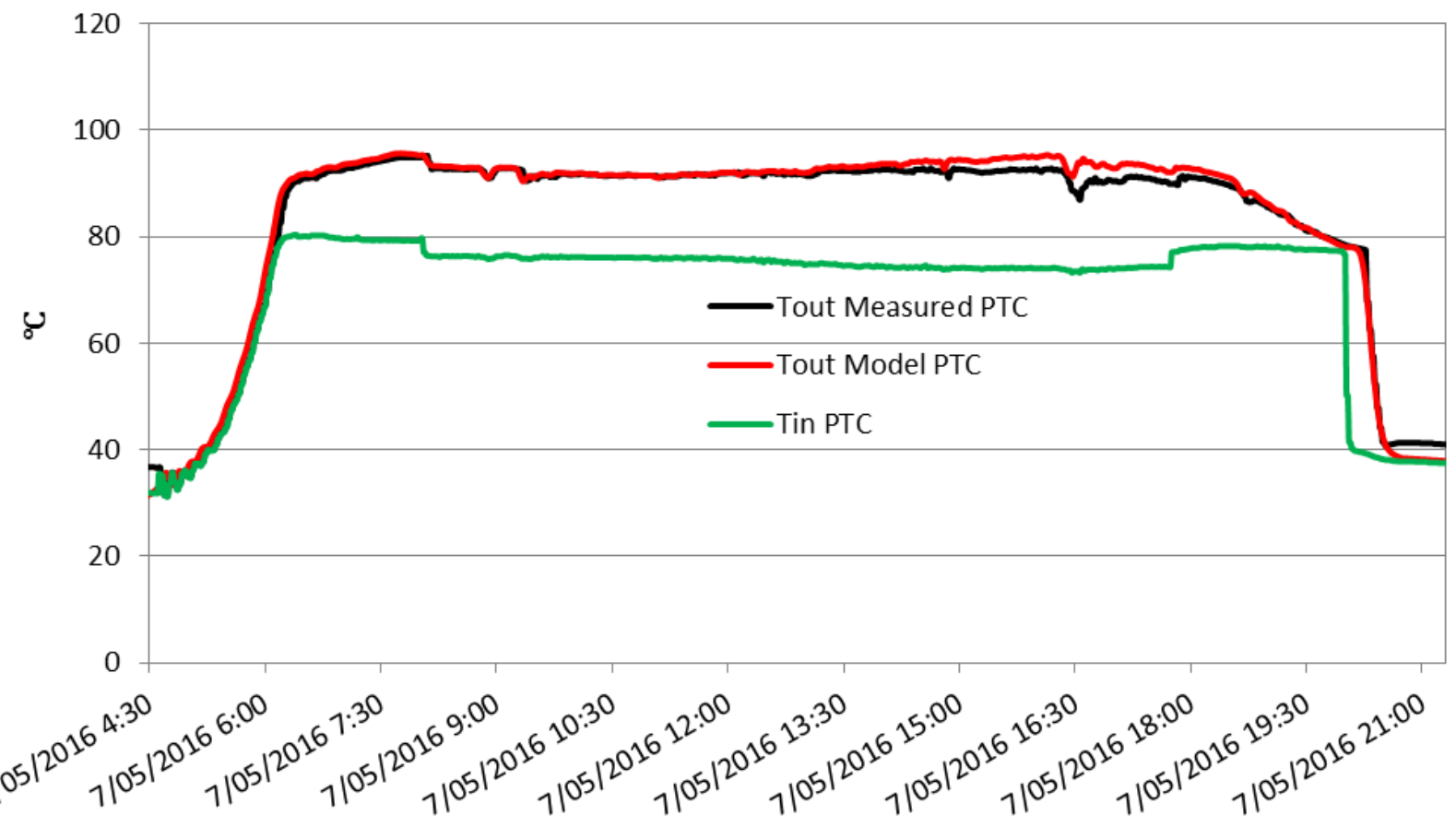

Fig.6. Inlet temperature, measured and modelled outlet temperature of the PTC field on the sunny day.

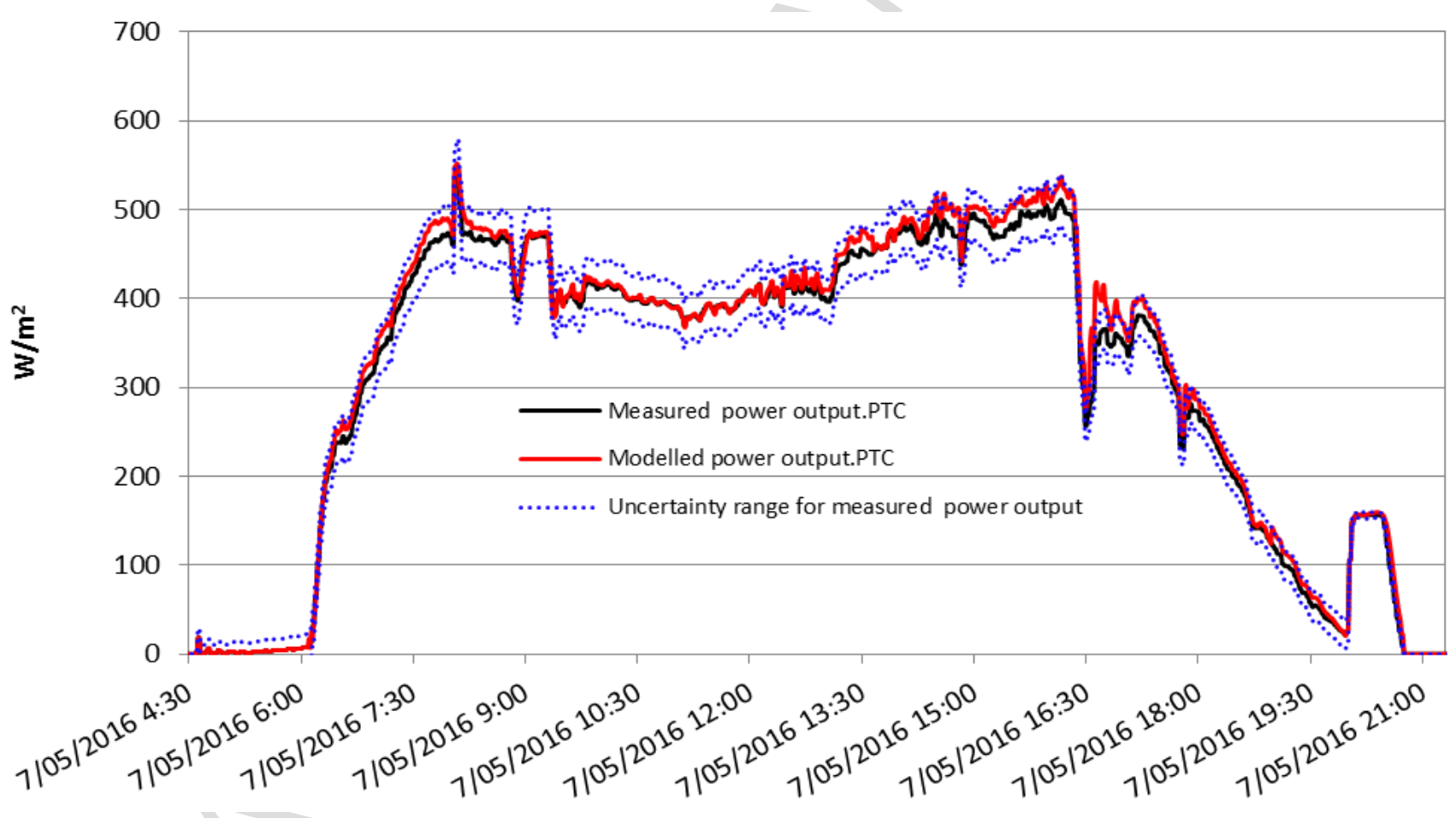




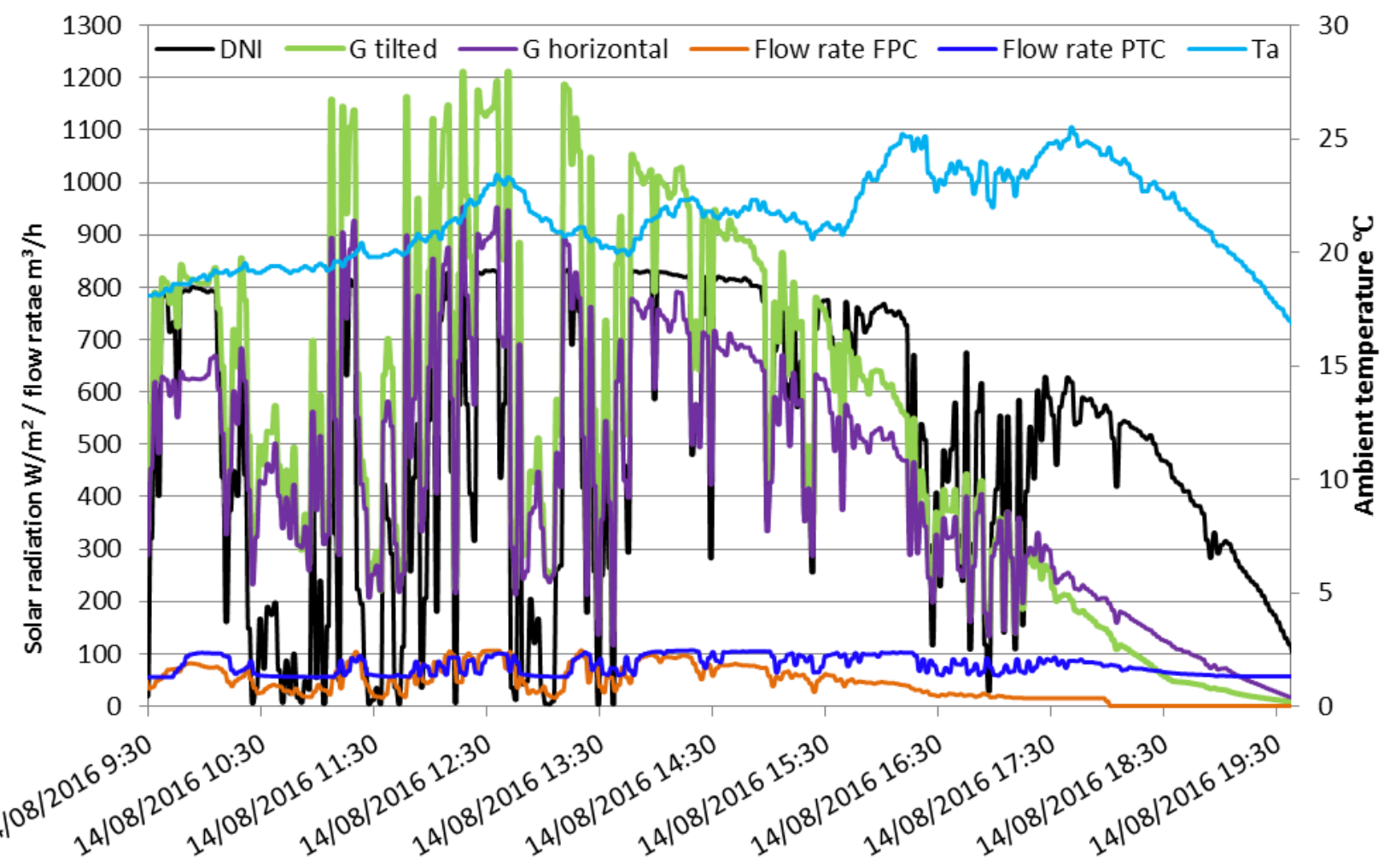

Fig.8. Global solar radiation, total tilted radiation, DNI, ambient temperature and flow rates on the cloudy 


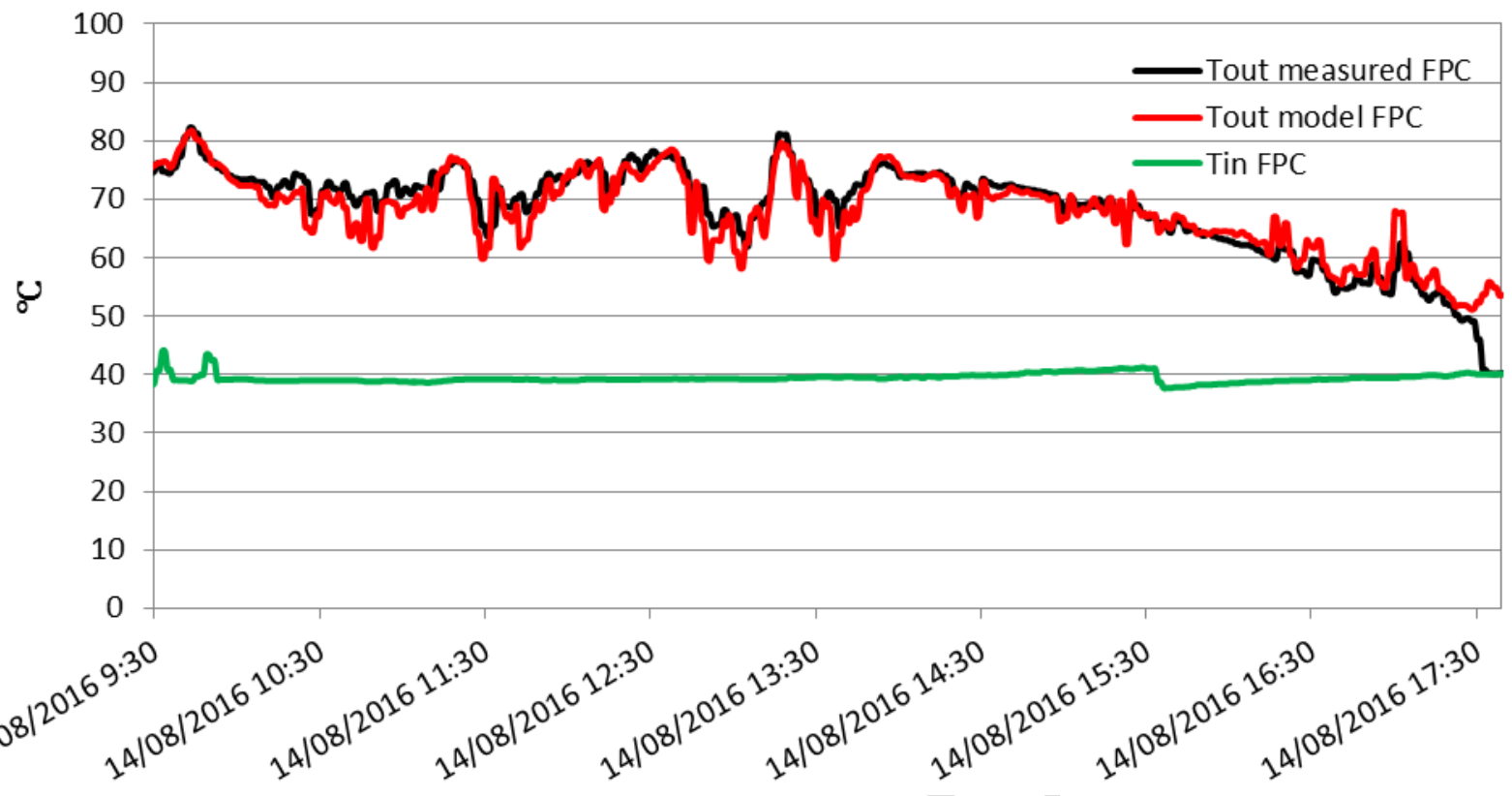

517 Fig.9. Inlet temperature, measured and modelled outlet temperature of the FPC field on the cloudy day.
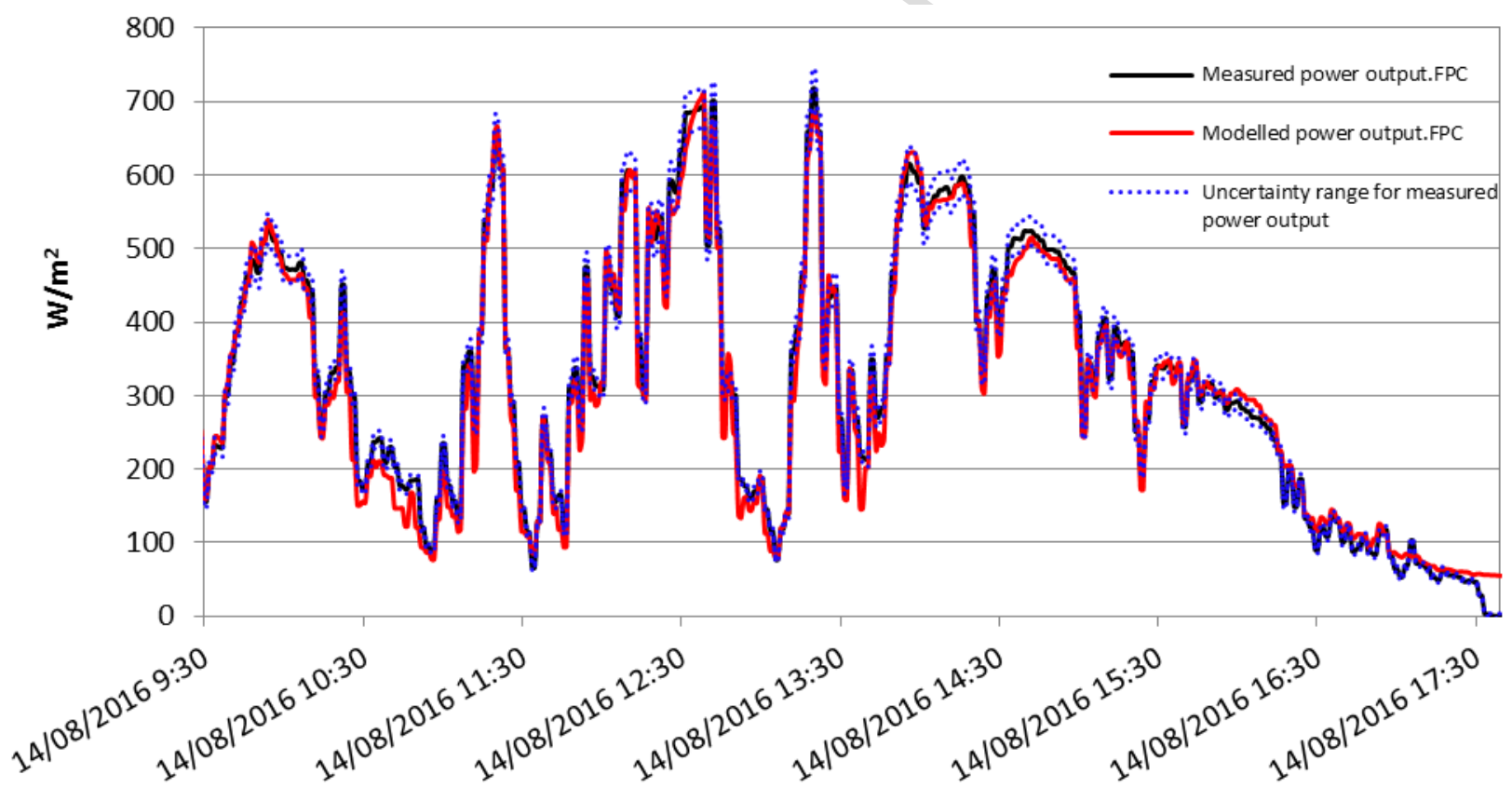

Fig.10. Measured and modelled power output of the FPC field on the cloudy day. 


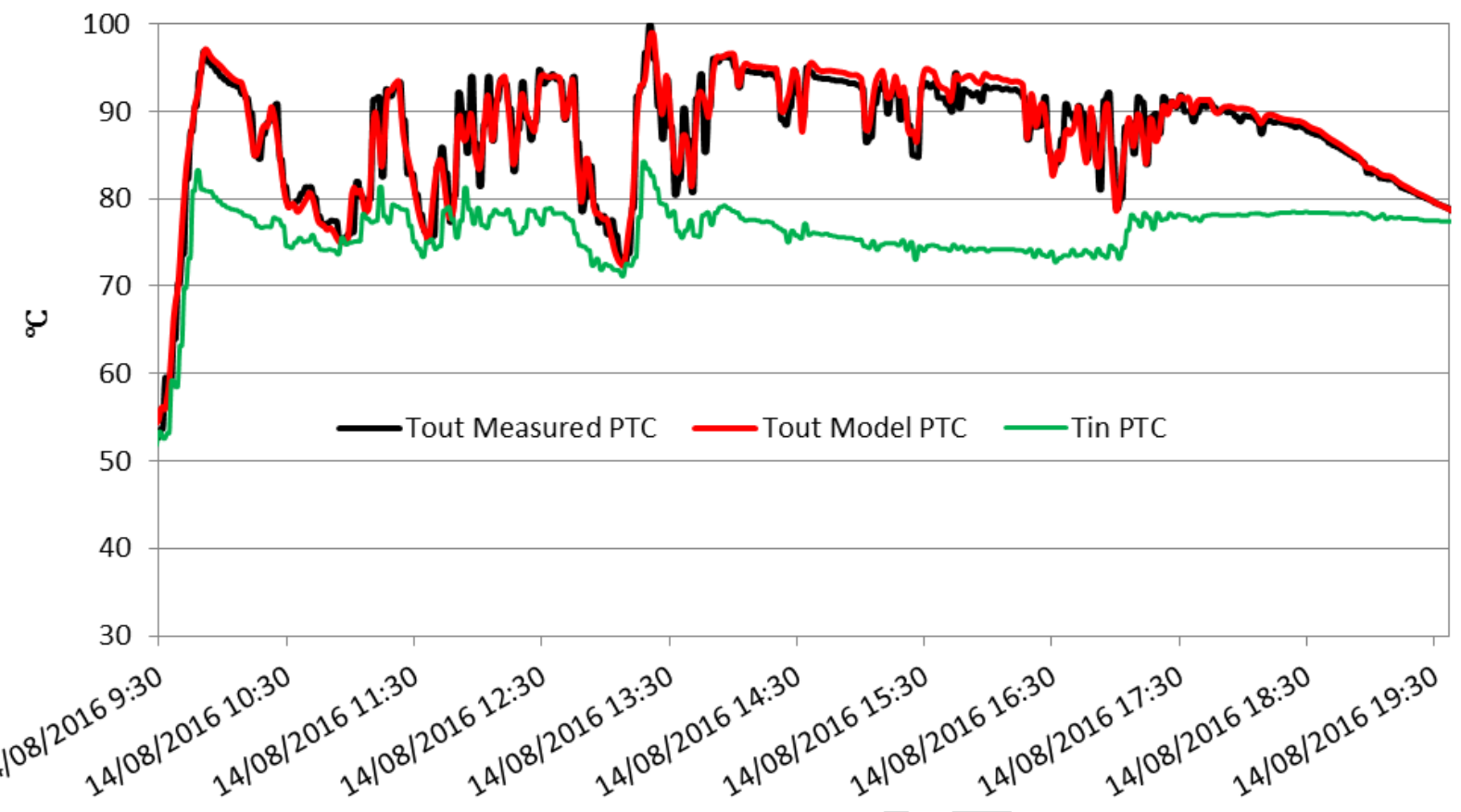

Fig.11. Inlet temperature, measured and modelled outlet temperature of the PTC field on the cloudy day.
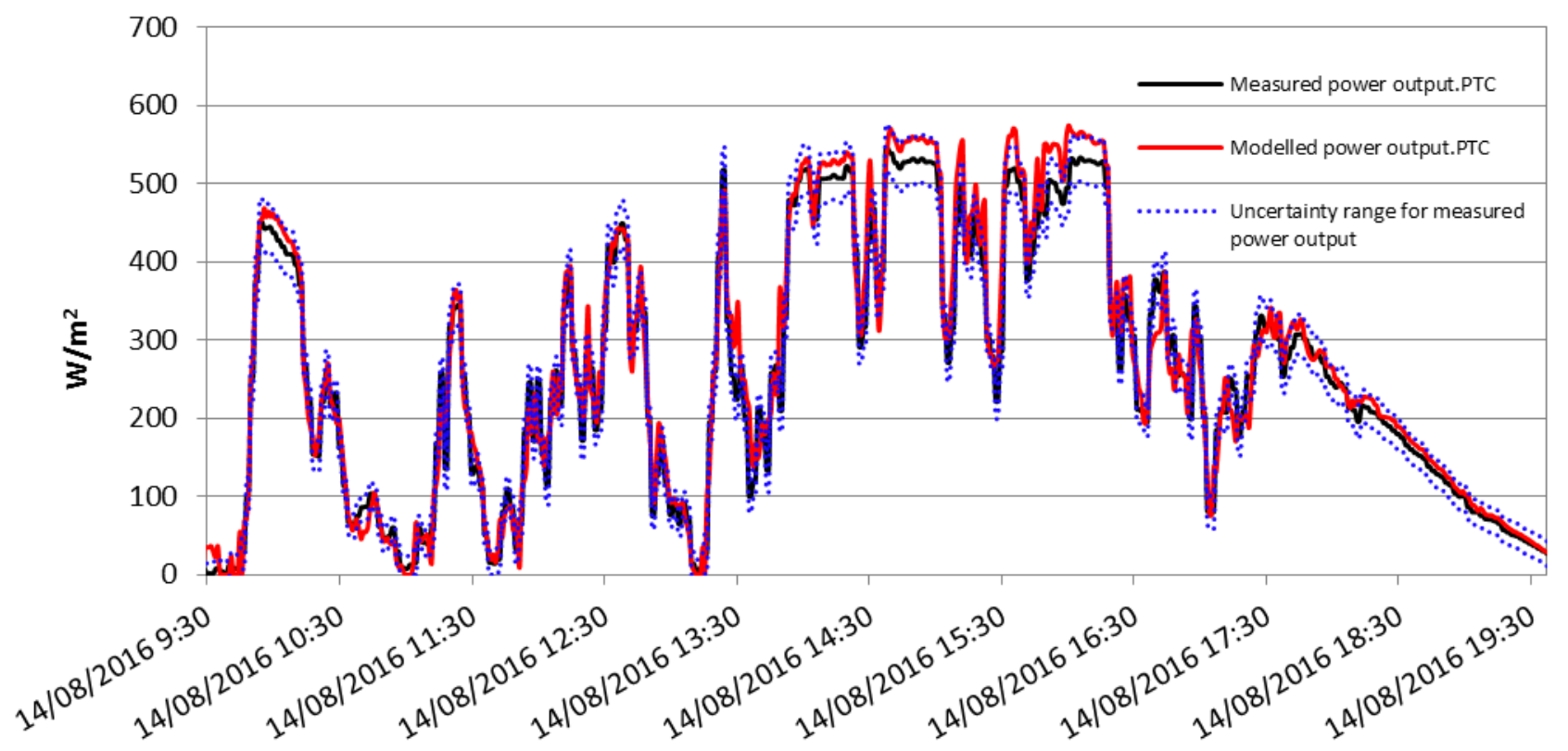

Fig.12. Measured and modelled power output of the PTC field on the cloudy day. 


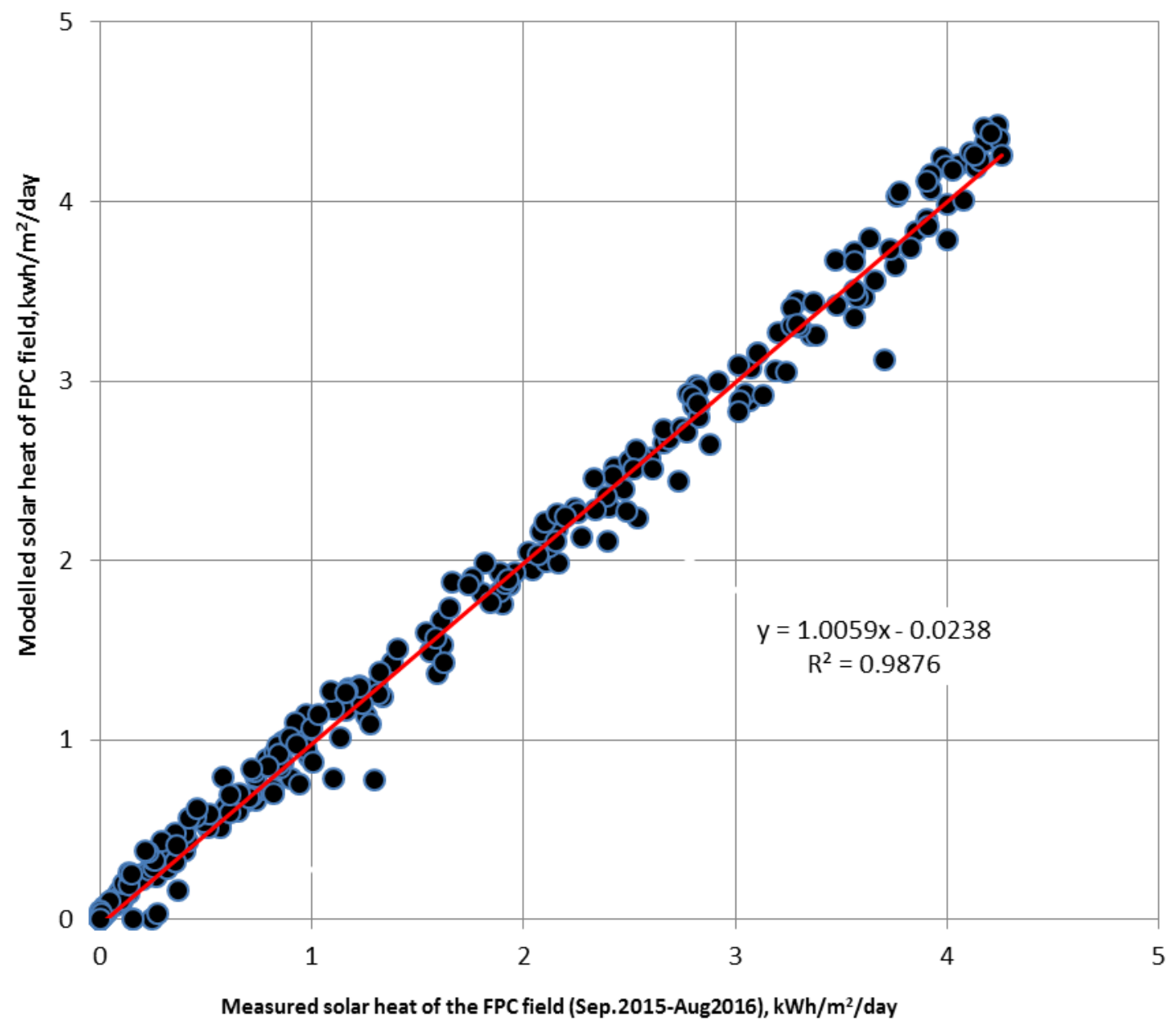

Fig.13. Daily modelled solar energy output as a function of daily measured solar energy output of the FPC field. 


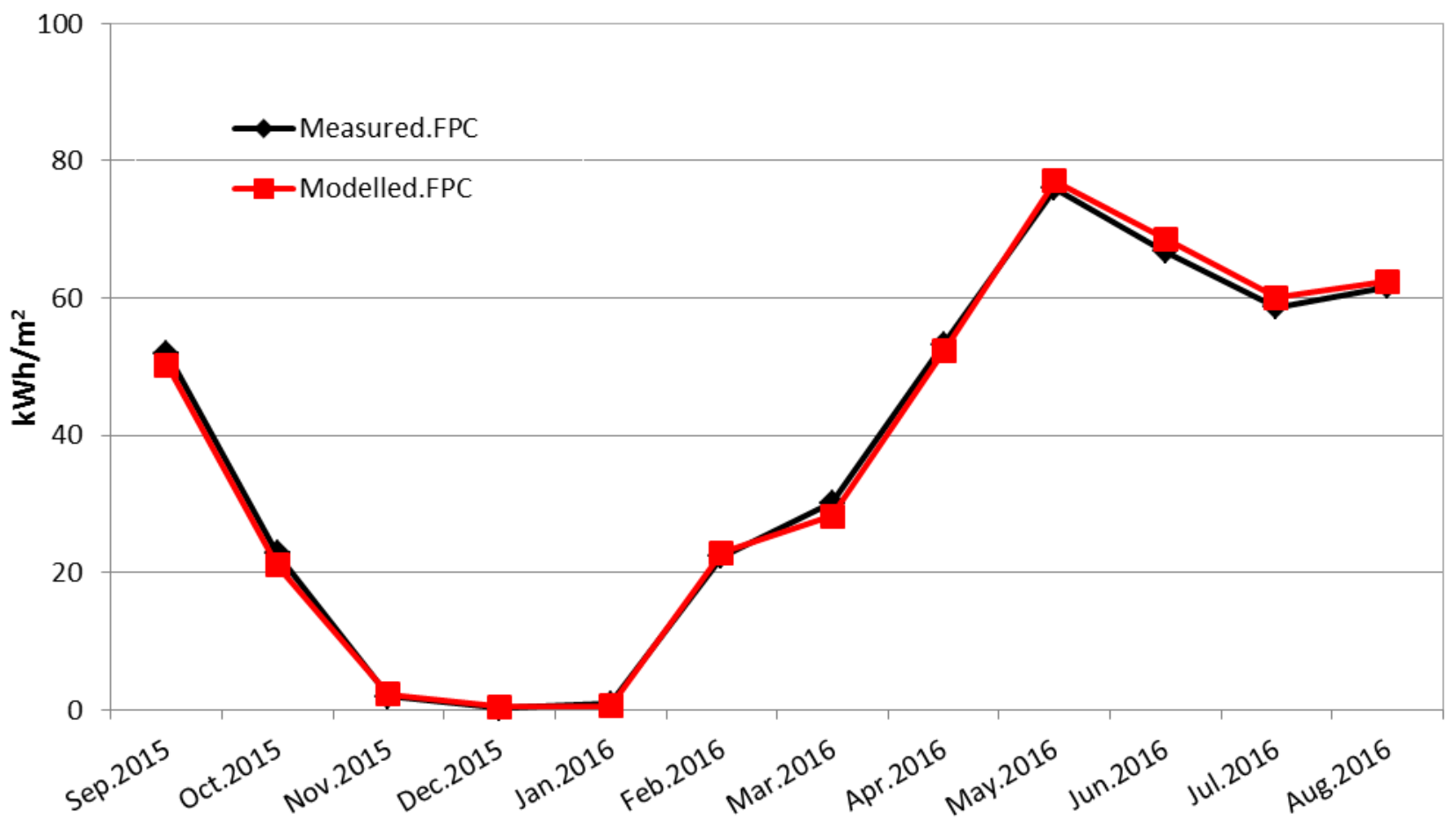

Fig.14. Monthly measured and modelled energy output of the FPC field (Sep.2015 - Aug.2016). 


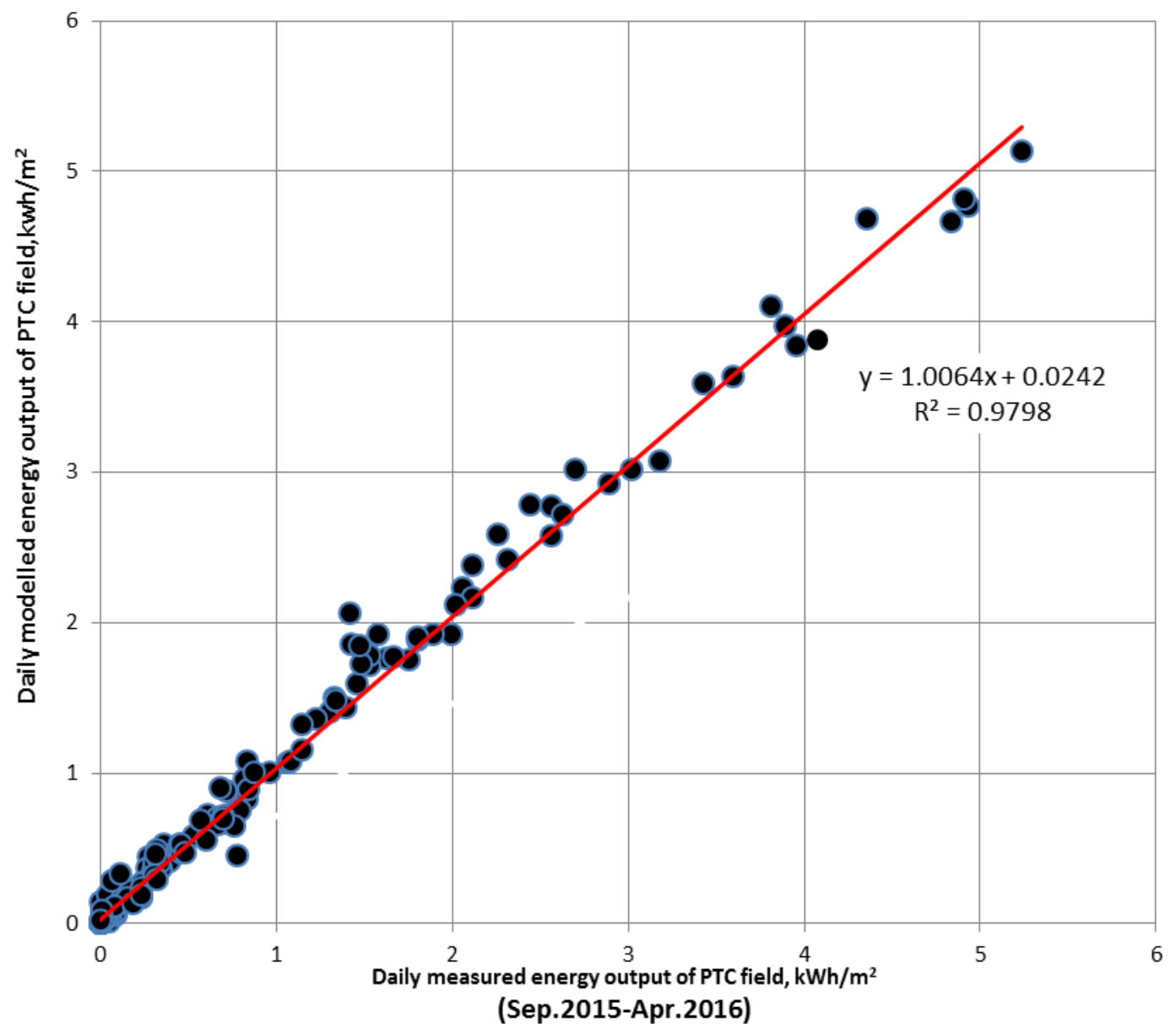

534

Fig.15. Daily modelled solar energy output as a function of measured solar energy output of the

PTC field. 


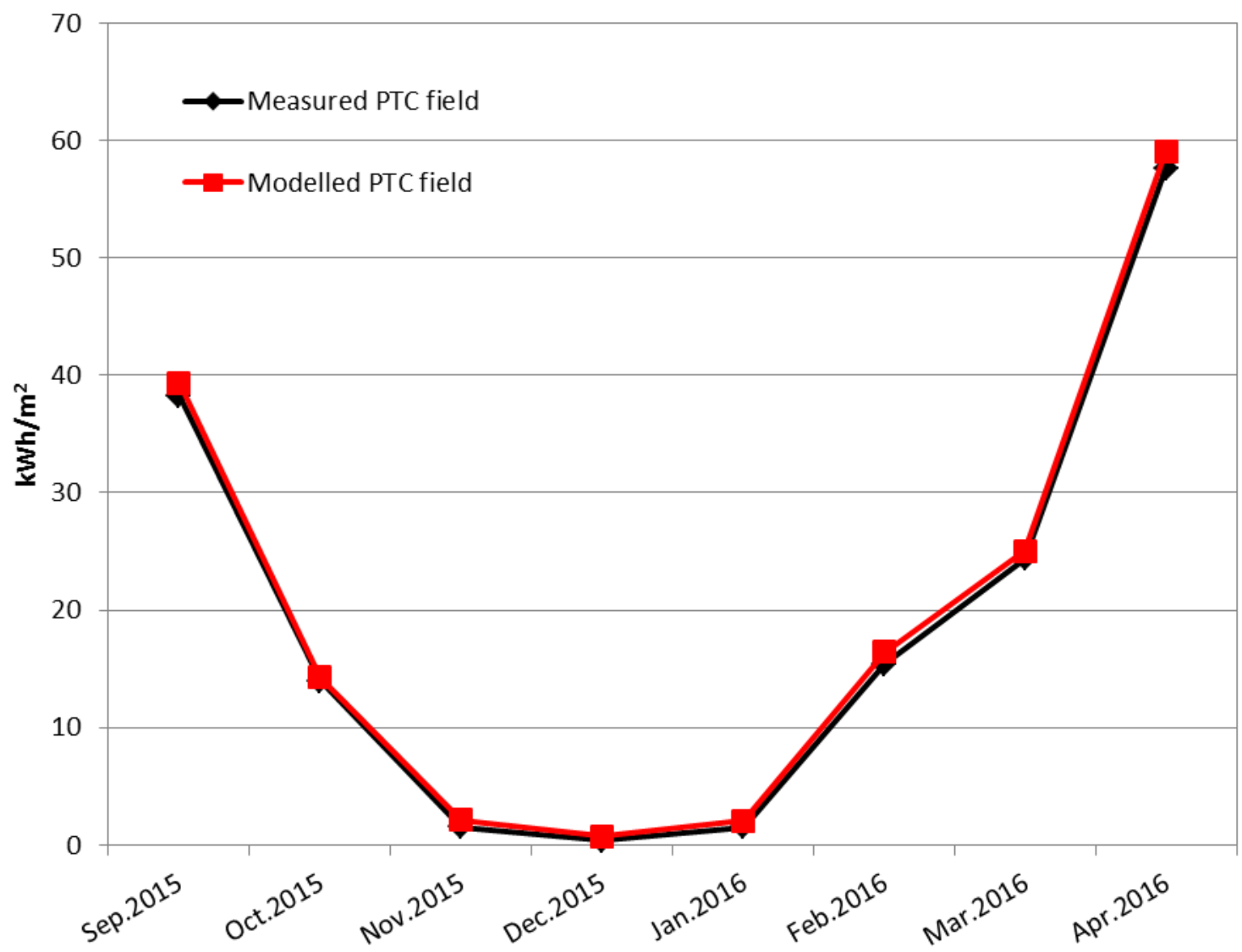

Fig.16. Monthly measured and modelled energy output of the PTC field. 